\title{
The Sign of the Flood and the Language of Signs in Babylonian Omen Literature
}

\author{
Andrew R. George \\ SOAS
}

The Babylonian Flood story contains a passage in which a god warns mankind of the coming Flood in cryptic terms. The passage appears in the Old Babylonian poem of Atram-hasīs as the following two lines, passage (a):

anāku ullîš ušaznanakku

hișbi isșūri bu-du-ri nūni

(OB Atram-ḩasīs III 34-35, Lambert-Millard 1969:88)

'Later I shall myself rain down upon you (sing.)

an abundance of birds, a profusion(?) of fish.'

This couplet terminates Enki's instructions to Atram-hasīs concerning the building of the boat in which he will survive the Flood, so it is certain that Enki is the god who sends this apparent promise of plenty. One word of the couplet remains a problem, i. e. bu-du-ri, but it is not the purpose of this paper to focus on this difficulty. ${ }^{1}$ The first-millennium text of this passage has not yet been recovered among the sources of the poem of Atram-hasīs that have recently been published (Al-Rawi-George 1996; Böck-Márquez Rowe 1999-2000; Lambert 2005). However, a version of the Flood story very close to that handed down in Atram-hasis was at some time interpolated into the Epic of Gilgameš, where the couplet (a) is embedded in a longer passage. The text is not yet completely recovered but what survives is given here as passage (b):

[urr]adma ana Apsî itti Ea bētīya ašbāku

ana kâšunu ušaznanakkunūši nuhšamma

[hiṣib] iș̣ūrāti puzur nūnīma

$i[l ?-\ldots]$ x x x x mešrâ ebūramma

ina šêr kukkī

ina līlâti ušaznanakkunūšs šamūt kibāti

(SB Gilgameš XI 42-47, George 2003:704-706)

\footnotetext{
${ }^{1}$ For different interpretations of bu-du-ri (profusion, reedshoot, object made of reed) see most conveniently Shehata 2001:136-137.
} 
'[I shall] go down to the Apsû, to live with Ea, my master, he will rain down on you (pl.) plenty:

[an abundance] of birds, a riddle(?) of fishes, [...] ... riches (at) harvest-time!

In the morning he will rain down on you (pl.) bread-cakes, in the evening, a torrent of wheat.'

In this passage of three couplets Enki's promise remains part of the god's instructions, but has been transferred into the mouth of the Flood hero, for this is what Ea wants him to tell the elders of his city Uruk. To take account of the new context the verb ušaznan is now third person and the second-person singular dative suffix has been made plural.

In the evolution of passage (a) into passage (b), Enki-Ea's promise has grown from two lines to five, and in doing so has accrued greater capacity for cryptic expression. What interests us here is the language of Ea's promise, particularly the last two lines, XI 46-47. These two lines seem to be more enigmatic than the three that precede them. They are repeated twice, with minor variants, as the plot develops, when they are written as single lines and are not accompanied by the other three lines (SB Gilgameš XI 88 // 91): ina šêr kukkī ina līlâti ušaznana (var. izannanu) šamūt kibāti. The compression of the couplet into a single line and its twofold repetition are probably poetic devices to emphasize the growing haste of the Flood hero's frantic preparations as time runs out. The singling out of this part of the promise, and the omission of the other three lines, reaffirms the importance of what is said specifically in this line: "in the morning he will rain down bread-cakes, in the evening a shower of wheat."

The history of interpretation of these lines has been given by Alan Millard in an article published twenty years ago under the title "The Sign of the Flood" (Millard 1987). Millard observed that, as long ago as 1921, scholars such as Arthur Ungnad and then Carl Franck had supposed that the lines contained word-plays on kukku "bread-cake" and kibtu "wheat," which allowed them to be interpreted as unfavourable outcomes, i. e. a prediction of disaster. He then showed that the particular grounds Franck cited in support of the puns turned out to be false, noted that the word-play theory was rejected by Wolfram von Soden, and concluded that the "word play has lost its basis."

Millard proposed another solution to the conundrum set by the sign of the flood. He observed that rains of wheat and other stuffs feature in the protases of omen texts, where they seem always to bode ill, and suggested that whoever expanded the text of Enki's warning with the lines 
in question had a knowledge of the language of omens. "It is in this context the sign of the Flood makes best sense, as an omen, which those who heard or read the story would recognize as a rare presage portending events of unaccustomed magnitude" (Millard 1987:67). Millard concluded that "to some well-educated Babylonian scribes reading the story of the Flood, and perhaps to a few of the public hearing it, the sign Ea promised would not be totally strange, and the diviners might recognize that it heralded disaster." For him the ambiguity lay not in word-play but "in the nature of the sign," meaning that the portent of strange precipitation automatically signified disaster. The outlandish rain foretold in Ea's promise was followed by the greatest catastrophe in human history, as the Babylonians saw it, and subsequently became an aetiology for the bad consequences of similar portents.

There is new evidence bearing on this topic. It comes from a Middle Babylonian tablet of liver omens, now in a private collection. The pertinent entry is passage (c):

BE manzāzu(KI.[GUB) ki-ma $k] u-u k-k i$ den-líl a-na mäti(KUR) a-na lemutti(HUL) $)^{t i} u ́-\ulcorner\check{s} a r\urcorner$

(MS 3176/2:10, George forthcoming)

"If the "station" [is like a] bread-cake: Enlil will descend on the land with evil intent.'

In its mention of kukku, a "bread-cake" in the customary translation, this omen is a broad vindication of Millard's general position, that Ea's promise in the story of the Flood uses the language of omens. But in its detail it offers a different solution, for ill-boding precipitation is not at issue here. The manzāzu "station" is a crease or groove on the left lobe of the liver. Its absence was ominous, and so too was its presence in an abnormal configuration, when it was a locus at which a sign appeared. In passage (c) the abnormal configuration is the crease's resemblance to a $k u k k u$. It happens that a first-millennium omen commentary tells us what shape is meant by the simile "like a $k u k k u$ ". This is passage (d):

BE manzāzu(NA) kīma(GIM) $k u k k i(\mathrm{GÚG}) a p p u\left(\mathrm{KIR}_{4}\right) u$ išdu(SUHUŠ)

${ }_{\text {gišk } k a k k a(\mathrm{TUKUL})} i b n \hat{u}(\mathrm{DU})-m a$ qabal( MURUB $\left._{4}\right)$-šú zu-qúr

(Manzāzu Commentary 1:106, Koch-Westenholz 2000:146-147)

“"If the 'station' is like a bread-cake": (i. e. its) tip and base are pointed (lit. form weapon-marks) and its middle is peaked.'

The comments appended to the protasis by the commentator give a description of how a feature of the liver can resemble a $k u k k u$. It comes to 
a peak in the middle and a point at both ends. The peaked middle of the $k u k k u$ is also noted in another omen commentary. This is passage (e), which elucidates a protasis describing the appearance of the $\check{s} u l m u$, a crease on the other lobe of the liver in the vicinity of the gall-bladder:

BE šulmu(SILIM) kìma(GIM) kukki(GÚG) qabal(MURUB 4 ) šulmi(SILIM) zu-q[úr] (Pān tākalti Commentary 3:28, Koch-Westenholz 2000:413)

" "If the 'well-being' is like a bread-cake": (i. e.) the "well-being's" middle is peaked.'

In both cases the imagery signifies a mark on the liver that takes the form of a short ridge whose middle is higher than its ends.

Returning to passage (c), here is a pairing of protasis and apodosis that very firmly makes the equation "kukku= Enlil plotting against mankind". As all knew well, Enlil's malevolence towards mankind was what brought about the series of disasters that punctuated early human history, culminating in the Flood. It seems that in divination the $k u k k u$ could be a harbinger of the Flood, if not also of the other disasters born of Enlil's antipathy to men. If Ea's promise in Gilgameš is couched in the language of divination it is the word kukku that is the key portent, not the rain, and it signifies not just disaster, but the specific catastrophes inflicted on mankind by Enlil: plague, drought, famine and Flood. The Flood was the most terrible of these, and left an indelible mark on the Babylonian world-view.

Despite Millard's misgivings, word-play has remained alive as a strategy used by scholars to explain how Ea's promise of bread-cakes and wheat signified a prediction of disaster. The false leads followed by Frank have been abandoned. Some have invoked the general notions of "double meanings and puns" (Dalley 1989:133; Tournay-Shaffer 1994:227) and "ambiguous language" (Foster 2001:84). Others have sought to apply to the problem the Babylonians' own techniques of bilingual hermeneutics, using Sumerian equivalences and Akkadian cognates true and false to explore connections between kukku, kibtu and an evil outcome (Bottéro 1992a:186, fn. 3; George 2003:511-512; Maul 2005:186).

The new evidence provided by passage (c) means that there is another avenue to be explored. The correspondence between $k u k k u$ and Enlil's wrath is there embedded in a semiological system of observation and prediction. The relationships of protases to apodoses in omen texts are one of the most elusive problems that attend any attempt at understanding the way in which Babylonian intellectuals configured their world. With some omens the connection was the result of empirical observation 
but an origin in reality cannot be attributed to the vast majority, for they were extrapolated as the compendia grew. It is reasonable to assume that protases and apodoses were elaborated according to a set of principles, a system of signs that may be called a Babylonian semiology. One such sign seems to be $k u k k u=$ Enlil's wrath. In the language of signs the word $k u k k u$ in the protasis matches the anger of the divine ruler of the world in the apodosis. One may go so far as to say, in the terminology of semiologists, that the word $k u k k u$ is the signifier, the bread-cake as a concrete object is the signified and the prediction associated with it (Enlil's wrath) is a second referent.

Some fundamental rules of the Babylonian system of signs as revealed by liver omen texts were identified by Ulla Jeyes (1980) and Ivan Starr (1983). Subsequently, in his study of Mesopotamian thought, Mogens Trolle Larsen identified three main elements that played a role in the relationship between protases and apodoses: (a) contrasting pairs or binary oppositions, (b) analogy, association and paranomasia, and (c) specific correspondences (Larsen 1987:213-214). Others have written specifically on what they have identified as analogy (Glassner 1984) and homophony (Greaves 2000). However, much of the system remains opaque. As Ann Guinan remarked in her study of left/right binary opposition in divination, "only rarely are we able to trace the conceptual link that reaches outside the world of appearances and apprehend the internal logic of a single omen" (Guinan 1996:5). The ancients themselves give us a little guidance. Some generalized associations between the portent and the observation are set out at the beginning of the extispicy series Multābiltu, now edited by Ulla Koch (Koch 2005:8-10). It is uncertain how far these statements represent extrapolation and how far they set out original principle.

Late first-millennium commentaries reveal that Babylonian scholars were themselves intrigued by the internal logic of entries in omen compendia, especially those of the diagnostic series (George 1992). The search for "internal coherence" is a particular hallmark of commentaries from the Late Babylonian private libraries of Uruk and Nippur (Frahm 2007:248). The manifold and ingenious strategies the commentators employed do not throw up any clear pattern, and show that, whatever logic had originally generated the pairing of most protases and apodoses, these commentators struggled to understand it much as we do.

One of the obvious and better-known ways in which protases and apodoses are related to each other is through phonetic similarity between 
the observation and the prediction. It is predictable but germane to quote in this connection an omen that has been much cited by writers on divination (YOS X, 24:9, see e. g. Cooper 1980; Bottéro 1992b:133): ina imitti martim pilšŭ šina palšùma šutebrû amūt Apišalîm ša Narām-Sîn ina pilšim ikmûšu "(if) there are two holes to the right of the gall-bladder and they go right through: the omen of the Apišalian, whom Narām-Sîn captured by tunnelling." While some would see this omen as founded in paranomasia (word-play), I think these terms are too trivial. The Babylonians had a different understanding of linguistics than we have, and found connections between words where we find none (Lambert 1999). It is clear from the lexical list Nabnitu that phonological similarity was an important factor in native etymology (Finkel 1982:31-36). Accordingly, an equation like pilšu palšu = Apišal is not inconsequential; on the contrary it asserts that the two sides of the equation were linguistically cognate. However misconceived we find this etymology, the equation sets out a correspondence that was considered real and meaningful. From the point of view of semiology, it is important to note that it is the word pilsu in its written or spoken form that generates Apišal in the apodosis. In the language of semiology, in this omen the signifier produces the sign.

Babylonian scholars evidently set great store on making connections between words in this way, so it is reasonable to presume that they employed their understanding of etymology in generating pairs of protases and apodoses, as omen compendia developed, as well as in the practice of hermeneutics. The double meanings, puns and word-plays cited by scholars attempting to relate kukku and kibtu in SB Gilgameš XI 46-47 to evil outcomes can be defended if they rest on equations that a Babylonian would find meaningful. It is very possible, therefore, that pseudo-etymology does underlie the pairing of the observation (Ea's promise) with the outcome (Enlil's flood).

There is another factor in the equation, however, and this is figurative interpretation. Figurative interpretations can be applied to the two basic structural elements of omen protases and apodoses, (a) things observed or predicted and (b) processes observed or predicted. These two elements may be called respectively idea and function. As we shall see, figurative interpretation of an idea produces a symbolic relationship between two things; figurative interpretation of a function produces an analogous relationship between two processes.

Symbolism in divination is explicit in the diviner's apparel and ritual apparatus, for the end of the text about the first diviner of legend, King 
Enmeduranki of Sippar, reveals that these mundane items were explicitly identified with divine forces (Lambert 1998:150-1533, 11. 78-130). In omen texts figurative associations are expressed by both symbolism and analogy. These are clearly seen to operate in some omens of malformed births. While Erle Leichty urged caution in identifying associations between observations and predictions in these omens (Leichty 1970:6-7), some are self-evident. In SB Izbu XVI, for example, the foetus's intestines symbolize property, for their exposure to sight signifies the vulnerability of property (1l. 39', 71': carted off by the enemy) and their absence signifies a lack of property (1. 43': famine and impoverishment). The same association already occurs as an analogy in an Old Babylonian forerunner, YOS X, 56 i 1-3, where intestines that spill out the foetus's belly signify the liquidation of assets, behaviour motivated by famine and impoverishment (Leichty 1970:201, read in $1.3[b] u-s ̌[a-\check{a} a$ a-na ma-h] $] i$-ri-im ú-̌̌i-iṣse "(the land) will send its possessions to market"). Symbolism and analogy were principles that already informed the earliest omen compendia.

The operation of symbolism in extispicy is a topic discussed briefly by Ulla Jeyes, who observed that "all fortuitous marks ... symbolize something. The hole was associated with death, the 'Weapon' with warfare, the 'Foot' with the approaching enemy, and the 'Wish' with a demand from the god" (Jeyes 1980:25). These are what Larsen called a "set of correspondences between specific features of the liver and phenomena in the physical world" (Larsen 1987:214); the ominous characteristics of these features had analogous effects on their counterparts in the larger world. Jeyes concluded that a "theory of symbolism can explain the connection between protasis and apodosis." The example she chose to illustrate the connection was an entry in an Old Babylonian compendium: [MAŠ e]lēnum bāb ekallim šilum šeli wāṣi abullim nēšsm idâk "[If] there is a hole gouged(?) above the Palace Gate [part of the liver], a lion will kill someone who goes out of the city gate" (YOS X, 26 ii 32, cf. Jeyes 1980: 32, fn. 73). The hole in the Palace Gate means death in the city gate, so there is a double equation of ideas: location (Palace Gate $=$ city gate) and mark (hole $=$ death). From the point of view of semiology, concrete objects, location and mark, generate the apodosis. In this omen it is the signified, not the signifier, that produces the sign.

If features of the liver and marks on them could have symbolic meanings for diviners, then it is not so improbable to suggest that the shape of these marks might also be interpreted by symbolism. On occasion this does indeed seem to be so, as can readily be seen from two entries in the 
same omen text that gave us passage (c). In passage (f) the correlation between the observed shape of the "station" in the protasis and the prediction cited by the apodosis is very clear:

BE [išid? manzā]zi kīma ziqit zuqaqīpi ikpup rubâ zuqaqīpu izaqqi[ssu]

(MS 3176/2:15)

'If [the base(?) of the "station"] curves around like a scorpion's sting: the prince will be stung by a scorpion.'

The curved crease known as the "station" prefigures a scorpion's sting because it resembles one. In passage $(\mathrm{g})$ the correlation is only slightly less easy to uncover:

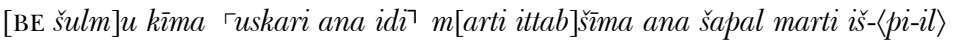
rìdi usurti

(MS 3176/2:33)

"[If the "well]-being" [has grown] like a crescent beside the gall[bladder] and reaches down to the bottom of the gall-bladder: (it signifies) a driving into encirclement.'

Here the crease known as the šulmu makes a loop that prefigures a military manoeuvre to trap the enemy. In both omens there is a clear figurative relationship between the portent and the prediction that rests in the first on an equation of ideas (symbolism) and in the second on an equation of functions (analogy).

On the topic of figurative language in omens, two points of caution have to be made. First, while some similes can be shown to have a symbolic interpretation, like the "station" that curves "like a scorpion's sting" in passage (f), others do not seem to produce meaning in this way, at least, as far as we can see. Many similes were perhaps for illustrative purposes only, and without symbolic value. Second, there is no overall consistency in the symbolism of shapes. Passage (c) establishes a connection between a shape like a kukku and Enlil's wrath. Other protases that liken portentous objects to a kukku occur in Šumma padānu I 23-24 (ed. KochWestenholz 2000:196), where a $k u k k u$-shaped "path" signifies a captured city, and Šumma izbu XVII 52' (ed. Leichty 1970:169), where the apodosis is broken. It seems that, unlike the symbolism of fortuitous marks noted by Jeyes, the symbolism of shape and form was less thoroughly worked out in the omen corpus. In her exploration of divinatory rhetoric in terrestrial omens Ann Guinan found that "divinatory meaning emerges from minimal rhetorical deviations when omens are integrated with each other in a restricted context, such as the same tablet" (Guinan 1989:232). 
The meaning is determined locally. Thus a kukku-shaped mark did not of necessity signify Enlil's hostility to mankind. But it did so in the company of the other omens that describe the manzāzu in terms of similes (MS 3176/2:1-16).

In the light of the prevalence of figurative association in omens I feel that the connection between the kukku "bread-cake" and Enlil's wrath in the omen passage (c) and SB Gilgameš XI (b) is just as likely to derive from a symbolic interpretation as from a word-play or pseudo-etymology. In other words, the sign could have been produced by the signified and not by the signifier. But I can get no further, because I do not know the Babylonians' language of signs.

From the point of view of the Babylonian intellectual, perhaps, a distinction between $k u k k u$ the signifier and kukku the signified would not be a major one, for both figurative and etymological speculation were essential components of Babylonian semiology. Eckart Frahm's important new study of Babylonian commentaries has found that figurative interpretation was used much less than graphic and phonetic hermeneutic techniques (etymography and etymology), but was nevertheless a technique employed in the decoding of signs (Frahm 2007:52). The same techniques were certainly employed in the codification of signs in omen literature, where, as we have seen, symbolic interpretation is everywhere visible. An important point emerges: in seeking connections between omen protases and apodoses, modern scholars will most profitably approach the problem if they bring to it the same knowledge of Babylonian semiology - the language of signs-as their ancient counterparts had. At the moment, that knowledge is only partly recovered; hence the frustrating struggles described in this paper.

The last question that arises is the question of date. Which came first, passage (b) of SB Gilgameš XI or passage (c), the entry in the Middle Babylonian omen text? Did the omen tradition assimilate a literary motif or did the literary composition adopt a divinatory motif? The omen text is difficult to date more exactly than Middle Babylonian. More is known of the history of the Flood story, and one can begin with passage (b). Passage (b) is a speech within a speech, for Ea is telling the Flood hero what to say. In fact, it is a speech within a speech within a speech, because in the poem of Gilgameš the whole story of the Flood is narrated by Utanapišti, the former Atra-ḩasīs. ${ }^{2}$ Thus Üta-napišti tells Gilgameš what Ea

\footnotetext{
${ }^{2}$ As we now know from a newly published LB fragment of the poem of Atram-hasīs, the name Ūta-napišti was given to the Flood hero only when he was
} 
told him to tell the elders. A comparable narrative development can be seen in the episode in which Gilgameš dreams of Enkidu, which is part of the poem's narrative in the Old Babylonian Pennsylvania tablet (OB II col. i) but reported in a speech of the prostitute Šambat in the first-millennium text (SB I). However, it is now clear that these two examples of narrative complexity were introduced into the poem at different times (George 2007). The history of the evolution of the poem was clearly very complex. This means that we have to be wary of dating the expansion of the single couplet (a), from which $k u k k u$ is absent, to the triple couplet (b), in which kukku is present. It is not yet possible to place in time the evolution of the couplet known to us as OB Atram-hasīs III 34-35 to the triple couplet known to us as SB Gilgameš XI 43-47. The change could have occurred before the Flood story was adapted to Gilgameš, during that adaptation, or (less probably) later. So the longer version of the passage, with its reference to $k u k k u$, may be original to a version of the poem of Atram-hasīs, or it may not. It may then have antedated the omen text, or it may not. In short, the chronological relationship of passages (b) and (c) cannot be determined from the history of the texts in which they appear.

If literary history leads to a dead end, there is still room for speculation based on more circumstantial evidence. Sîn-lēqi-unninni, and others like him, were scholars. To judge from the distinguished example of Esangil-kīn-apli in the eleventh century, the editorial work of standardizing texts was carried out by very learned men indeed (Finkel 1988; Lambert 2005:xv-xviii; Al-Rawi-George 2006:54-55; Frahm 2007:255-261). It would fit what we know of the background of scholars like him, that texts they standardized should bear the imprint of their education and learning. It thus seems more likely to me that the omen of the $k u k k u$ and Enlil's wrath informed the expansion of passage (a) into passage (b) in the Flood story, rather than that the omen (c) was itself generated by a knowledge of the kukku motif in the Flood story.

Millard noted that the use of divinatory language in the passage of Gilgameš brought to the Flood story a logical detail that contrasts the Flood hero's knowledge with the ignorance of the townsfolk: "to Ut-na-

translated into an immortal (Lambert 2005:198, v 17): at-t[a-m]a ${ }^{\mathrm{I} z i-s u ̀-u d-r a ~ l u-u ~}$ UD-napišti(ZI) ${ }^{t i m}$ [šùm-ka] "You were Ziusudra, but let [your name] (now) be Ūtanapišti." In SB Gilgameš the Flood hero is called Atra-hasīs in the narrative of the Flood itself (SB XI 49, 197), but is otherwise Utta-napišti. This is a consistent application of the same idea, that Utta-napišti came by that name only after the Flood. 
pishtim's doomed countrymen the sudden outpouring of heavenly bounty would not carry any baleful message ... for only he had learnt the secret plan of the gods" (1987:68-69). More specifically one might add that Atram-hasīs, the antediluvian king of Šuruppak, was learned in the art of reading the language of signs, as his name "Surpassing-Wise" suggests, while the townsfolk were not. In ancient Mesopotamia divination was jealously guarded knowledge, and the illiterate were not privy to it. By contrasting the Flood hero's understanding of the language of signs with his people's ignorance of it, the learned editor responsible for interpolating the $k u k k u$ motif into the Flood story implicitly claimed Atram-hasīs as a fellow scholar. In doing so he projected on to the remote, mythical past a Babylonian intellectual's chauvinistic view of the importance of scholarship in general and divination in particular. This is fully in accord with the Babylonian myths of the Seven Sages and the divine origin of learning, and specifically with the diviners' own tradition that their secret language of signs was imparted by the gods Šamaš and Adad to another antediluvian king, Enmeduranki of Sippar.

\section{References}

Al-Rawi-George 1996

Al-Rawi-George 2006

Böck-Márquez Rowe 1999-2000

Bottéro 1992a

Bottéro 1992b

Cooper 1980

Dalley 1989

Finkel 1982

Finkel 1988

Foster 2001
Al-Rawi, F. N. H.; George, A. R. Tablets from the Sippar library VI. Atra-hasīs. Iraq 58:147-190.

Al-Rawi, F. N. H.; George, A. R. Tablets from the Sippar library XIII. Enūma Anu Ellil XX. Iraq 68:23-57.

Böck, B.; Márquez Rowe, I. MM 818: A New LB Fragment of Atra-hasīs I. AuOr 17-18:167-177.

Bottéro, J. L’épopée de Gilgaměs, le grand homme qui ne voulait pas mourir. Paris.

Bottéro, J. Mesopotamia: Writing, Reasoning, and the Gods (transl. Z. Bahrani and M. Van De Mieroop). Chicago.

Cooper, J. S. Apodotic Death and the Historicity of "Historical" Omens. Alster, B. (ed.). Death in Mesopotamia. Papers Read at the XXVIe Rencontre Assyriologique Internationale. Copenhagen. Pp. 99-105.

Dalley, S. The Myths of Mesopotamia. Oxford.

Finkel, I. L. The Series SIG $_{7}$.ALAN = Nabnìtu (MSL 16). Rome.

Finkel, I. L. Adad-apla-iddina, Esagil-kinn-apli, and the series SA.GIG. Leichty, E.; deJong Ellis, M.; Gerardi, P. (eds.). A Scientific Humanist: Studies in Memory of Abraham Sachs. Philadelphia. Pp. 143-159.

Foster, B. R. The Epic of Gilgamesh. New York. 
Frahm 2007

George 1992

George 2003

George 2007

George forthcoming

Glassner 1984

Greaves 2000

Guinan 1989

Guinan 1996

Jeyes 1980

Koch 2005

Koch-Westenholz 2000

Lambert 1998

Lambert 1999

Lambert 2005
Frahm, E. Origins of Interpretation. An Introduction to Babylonian and Assyrian Text Commentaries. Unpublished Habilitationsschrift. Philosophische Fakultät der RuprechtKarls-Universität Heidelberg.

George, A. R. Babylonian Texts from the Folios of Sidney Smith. Part Two: Prognostic and Diagnostic Omens. RA 85:137-167.

George, A. R. The Babylonian Gilgamesh Epic: Introduction, Critical Edition and Cuneiform Texts. 2 vols. Oxford.

George, A. R. The Civilizing of Ea-Enkidu: An Unusual Tablet of the Babylonian Gilgameš Epic. RA 101:59-80.

George, A. R. Babylonian Divinatory Texts in the Schøyen Collection.

Glassner, J. J. Pour un lexique des termes et figures analogiques en usage dans la divination mésopotamienne. JA 272:15-46.

Greaves, S. W. Ominous Homophony and Portentous Puns in Akkadian Omens. Noegel, S. B. (ed.). Puns and Pundits. Word Play in the Hebrew Bible and Ancient Near Eastern Literature. Bethesda. Pp. 103-113.

Guinan, A. K. The Perils of High Living: Divinatory Rhetoric in Šumma Ālu. Behrens, H.; Loding, D.; Roth, M. T. (eds.). Dumu-E ${ }_{2}$-DUB-BA-A. Studies in Honor of Ake W. Sjöberg. Philadelphia. Pp. 227-235.

Guinan, A. K. Left/Right Symbolism in Mesopotamian Divination. $S A A B$ 10:5-10.

Jeyes, U. The Act of Extispicy in Ancient Mesopotamia: An Outline. Assyriological Miscellanies 1:13-32.

Koch, U. S. Secrets of Extispicy. The Chapter Multābiltu of the Babylonian Extispicy Series and Nișirti bārûti Texts Mainly from Ǎ̌šurbanipal's Library (AOAT 326). Münster.

Koch-Westenholz, U. Babylonian Liver Omens. The Chapters manzāzu, padānu and pān tākalti of the Babylonian Extispicy Series Mainly from Aššurbanipal's Library (CNIP 25). Copenhagen.

Lambert, W. G. The Qualifications of Babylonian Diviners. Maul, S. M. (ed.). Festschrift für Rykle Borger zu seinem 65. Geburtstag am 24. Mai 1994 (CM 10). Groningen. Pp. 141-158.

Lambert, W. G. Babylonian Linguistics. Van Lerberghe, K.; Voet, G. (eds.). Languages and Cultures in Contact. At the Crossroads of Civilizations in the Syro-Mesopotamian Realm (CRRAI 42). Leuven. Pp. 17-31.

Lambert, W. G. No. 42. Atra-ḩasīs. Spar, I.; Lambert, W. G. (eds.). Cuneiform Texts in the Metropolitan Museum of Art. 2. Literary and Scholastic Texts of the First Millennium B. C. New York-Turnhout. Pp. 195-201. 
Lambert-Millard 1969 Lambert, W. G.; Millard, A. R. Atra-hasīs. The Babylonian Story of the Flood. Oxford.

Larsen 1987 Larsen, M. T. The Mesopotamian Lukewarm Mind: Reflections on Science, Divination and Literacy. RochbergHalton, F. (ed.). Language, Literature, and History: Philological and Historical Studies Presented to Erica Reiner (AOS 67). New Haven. Pp. 203-225.

Leichty 1970 Leichty, E. The Omen Series Šumma Izbu (TCS 4). Locust Valley.

Maul 2005

Maul, S. M. Das Gilgamesch Epos. Munich.

Millard 1987

Millard, A. R. The Sign of the Flood. Iraq 49:63-69.

Shehata 2001

Shehata, D. Annotierte Bibliographie zum altbabylonischen Atram-hasīs-Mythos Inūma ilū awīlum (GAAL 3). Göttingen.

Starr 1983 Starr, I. The Rituals of the Diviner (BiMes 12). Malibu.

Tournay-Shaffer 1994 Tournay, R.; Shaffer, A. L'épopée de Gilgamesh (LAPO 15). Paris. 